\title{
A CROSS-SECTORAL STUDY OF VALUE PROFILES AND DIFFERENCES BETWEEN EMPLOYEES IN PRIVATE AND PUBLIC SECTOR IN SOUTH EAST EUROPE
}

Ljuan Marko Gashi, Zeljko Pozega, Boris Crnkovic

\section{Abstract}

This study of cultures across 6 countries (7 regions) shows that each region has its own specificity and its own unique employee value profile. Value profiles have been explored as a potential diagnostic tool on the basis of Hofstede's value dimensions in the service of human resource development at the local level. The resulting employee value profiles are based on a representative sample of employees in the private and public sectors. Significant similarity in value profiles have been found for employees from Croatia and Serbia compared to Romania, Hungary, Slovenia and Italy, both in the public and private sector. The research results suggest the direction that managers and policymakers need to take in order to understand what employees' values are, how they can be used, and how to address the challenges of human resource development in their region.

Keywords: employees, private/public sector, enterprises, local administrative units, countries, regions, human resources, value dimensions.

\section{JEL classification: M50}

\section{INTRODUCTION}

The research questions raised in this paper are: What are the differences in value dimensions between employees in public and private sector? In what way can employees' value profiles be compared and how can they assist in the selection of strategies for development of human capital at local level? This research follows the study of cultural differences in international management by Geert Hofstede. We offer a methodological contribution to the study of value dimensions, i.e. value profiles, which can be compared and used as a diagnostic tool in human resource management (HRM), with various possible applications. The countries of interest to us are Croatia, Serbia, Hungary, Romania, Slovenia and Italy.
Ljuan Marko Gashi, PhD

Chair of Production Systems, Organization and Management

Faculty of Technical Sciences, Novi Sad, Serbia

E-mail:Imgashi@gmail.com

Zeljko Pozega, PhD

Chair of Economics and Business Management, Faculty of Economics in Osijek, Croatia

E-mail: zpozega@efos.hr

Boris Crnkovic, PhD

Chair of Economics and Business Management, Faculty of Economics in Osijek, Croatia

E-mail: bcrnko@efos.hr 


\subsection{Hofstede value dimensions of organizational culture}

Hofstede describes culture as the "collective programming of the mind" that distinguishes members of one group of people from another (Hofstede 2001). Hofstede first reduced the differences between cultures to four basic dimensions. All other differences, he argued, can be found in one or more of these dimensions: Power Distance Index (PDI), Individualism versus Collectivism (IDV), Masculinity versus Femininity (MAS) and Uncertainty Avoidance Index (UAI). After additional research, he added Long Term Orientation versus Short Term Normative Orientation (LTO) (Hofstede and Hofstede 2005) and Indulgence versus Restraint (Hofstede and Minkov 2010).

PDI or concentration of power shows the extent to which a society accepts the fact that the power within institutions and organizations is unevenly distributed among individuals. PDI is about hierarchy, i.e. what is considered a normal work process and the right to participate in decision-making. In some countries it is common to follow the person in charge, while in others people in leadership positions and employees relate to each other on the basis of equality. In societies/ organizations with high PDI, centralization is popular (Hofstede and Minkov 2010).

UAl shows the degree to which a society/organization feels threatened by uncertainty and in which situations tries to avoid them by providing rules or other means to ensure safety. UAI relates to the extent to which people are willing to take this risk. It is the extent to which people want their behaviour (and the behaviour of others) to follow certain predictable patterns. This dimension is about how much space exists for coincidence, improvisation, or letting things go their own way (even if it is the wrong way). While some people prefer only clearly defined instructions, others can handle open instructions or questions (Struch, Schwartz and Van der Kloot 2002).

IDV indicates the extent to which social frameworks exist and to what extent the individual is expected to care only about him/herself and his/her immediate family/group. Individualistic cultures clearly distinguish between one's own and others' social groups. In collectivistic cultures it can be difficult for a person to look for the possibility of individual action, or it may be unsatisfactory not to participate in group activities. High individualism emphasizes personal characteristics, individual initiative and achievement, the ideal of leadership and management. Work tasks are above connections and kinship and decisions on employment depend on knowledge, skills and rules. Management in individualistic cultures is the management of individuals, wherein one believes in individual decision-making processes and private solutions. Freedom, independence and equality are promoted, which can then turn into the value of universalism (McEwan 2001).

MAS indicates the extent to which gender determines the roles that men and women have in society. If the role of gender in a country is clear, it is dominated by men. Masculine organizational culture is characterized by competitiveness, awards and the values of recognition, promotion, initiative, achievement and challenge. Society is feminine when the sex roles overlap, so both men and women are considered modest and gentle, focused on the quality of existence. Feminine organizational culture is more inclined to compromise, negotiation and intuition than masculine organizational culture (Feather 2004).

LTO shows the extent to which a society bases its decisions on tradition and events from the past or how much they are based on short-term, current income, in contrast to what is desired in the future. It is about commitment, respect for tradition and hard work, which pays off gradually because business can develop more and more. For short-term orientation, changes may occur faster and liabilities and tradition do not slow down the process. The LTO shows how important the history of a particular area is for the present and future, and to what extent people tend to be proud of their origin (Spangler 1992).

\subsection{National culture and work}

Croatia, as a transitional, post-communist country still has low innovation capacity and suffers from a social capital deficit. It is burdened by traditional values considered to be dysfunctional for innovation, such as cooperativeness deficiency, low trust in institutions, state paternalism, and opportunism. Croatians are in general sceptical or conservative about new ideas or methods from both locals and non-locals. Although Croatians are direct in communication, they do not tend to openly offer constructive critics to colleagues about their performance at work. This is partly due to the belief that a person cannot be changed. Typically, workers express opinions about their dissatisfaction when a particular job is complete (Gilliland 1995; Glenny 2000). In Croatia, Hofstede's value dimensions have been used to determine regional differences (Rajh, Budak, and Anić 2016), potential for innovation (Lažnjak 2011), comparison with other countries (Podrug, Filipović, and Stančić 2014) and with regard to examination of a specific value dimension (Matic 2006). 
According to Falkné Bánó (2014), Hungarian business culture has less respect for management positions; hierarchy no longer plays an important role at the workplace. It is assumed that there is no strong link between employees' performance and commitment to their organisation. The social dimension of work remains important to achieve satisfaction at work. Achievement-orientation in Hungarian culture can be interpreted as a desire for a performancefocused work environment. Hungarian employees reject tough and aggressive behaviour and value assertiveness. In traditional organizations recognition was not linked to performance. As a result, employees were unmotivated to use their capabilities at a level higher than minimally necessary (Bakacsi and Takács 1998; Bakacsi et al. 2002). Some studies suggest that Hungarians are very operative and autocratic, although creative and flexible (Molnár 2004).

Cohen and Federico (2001) define Italy as one of the world's richest and economically advanced countries due to the fact that small Italian firms benefited from unique social interactions resulting from shared values and belief systems. Italy is associated with other countries that tolerate more power distance (Tavanti 2012). While Italians accept and somehow expect that some groups in society will be more powerful than others, they often express cynicism about persons in positions of authority, generally supporting the breaking of petty rules, ridiculing authority or people in positions of power (Flower and Falassi 2006). Italians 'avoid risk and uncertainty' in everyday life, prefer friends over strangers and familiar over new or strange situations (Gannon and Pillai 2010). With regard to managerial culture, in high-potential management men are preferred (Traquandi and Castellucci 2002).

In Romania, there are studies that refer to similar values with other Balkan countries (Luca 2005) and ex-communist countries, with the perception of inequalities as expected and desirable (Muruntelu 2010). While management strategies applied in Romanian companies are characterized by difficulties in planning, lack of innovation, evolving instability, the most frequent form of organisation is pyramidal, while employees prefer a more casual rather than competitive surrounding (Rusu, Isac, and Cureteanu 2015). It is also estimated that in the future individualism will increase with Romanian job market penetration by multinational companies and consistent foreign investments (Marinaş 2010). Bodea presents a model which shows significant links between the beliefs, values, attitudes and behaviours of Romanians: excellence influences attitudes toward work as expressed through behavioural characteristics - discipline, skills, professionalism; valuing honesty is associated with the spirit of family, hospitality and freedom; confidentiality is negatively correlated with the tendency to betray; power correlates with the desire to be a leader and with pride and stubbornness; inclination towards adventure is correlated with creativity, innovation, spontaneity and fun (Bodea 2013).

Slovenian managers are characterised by low power distance and high individualism, while high uncertainty avoidance prevails (Jazbec 2007). Slovenian entrepreneurs primarily value achievements, but lack the element of risk-taking; they prefer predictable and stable situations. The reason for this lies in the value of obedience and security in general, and in the avoidance of making mistakes, which is strongly present (Jazbec 2005). Obedience was highly encouraged in the school system in Slovenia, where the ideal student was one who was able to repeat the teacher's knowledge (Trstenjak 1991). When uncertainty avoidance is encouraged, then experimenting, imagination and the motivation to be different are suppressed, which presents an obstacle to a society to become innovative (Jazbec 2005). Slovenian managers prefer a feminine organisational culture (Prašnikar, Pahor and Vidmar 2008).

As a consequence of the turbulent recent past in the Balkans, Serbia has been suffering economic crises, hyperinflation, a UN embargo and problems with privatisation. According to Gordy (1999), Serbian culture is characterised by a conflict between the traditional rural values that were in power throughout the 1990s and the modern urban values of Belgrade and other cities that took charge after 1999. A comparative study of Prašnikar, Pahor and Vidmar (2008) concludes that Serbians have a more mechanistic (insider) view of the world and ascribe more importance to status. According to Cerović and Aleksić (2005), Serbian tradition, experiences with socialism and nationalistic ideology have revived these values, while the past, more than the present or future, plays an important role in the culture of the Serbian people. The findings of Mojić (2003) present Serbian culture as characterised by small power distance, high uncertainty avoidance and masculinity.

\section{APPLICATION OF CULTURE IN HRM}

There is a high intertwinement between all of Hofstede's model dimensions and the basic functions of HRM. PDI can be directly applied in the company through the determination of an organizational structure model, the way that organizations work and their decision-making systems. PDI has direct impact on 
setting, maintaining or improving the border of authority in the company, which methods will be used to achieve authority and strengthen it, how to balance inequalities in participation in business processes, how to prevent the discontent of workers and how to raise their motivation. PDI can be visible in the process of selection and recruitment, as it can show the organization's functioning and existing power system. PDI may affect the system of rewards and sanctions by which a manager can neutralize dissatisfaction or, in turn, further boost dissatisfaction with incorrect decisions or an unfair rewards system. UAI mostly finds its application through the processes of job analysis and the delegation of tasks and teams, and consequently through employees' performance management as a separate function of HRM. IDV places emphasis on individual initiative and achievements, especially contributing to the selection of new employees, matching skills and rules, individual and team work. In the context of HRM it is extremely important to stimulate employee innovation and the autonomy of the individual decision-making process and thus increase efficiency. IDV is applicable in companies through the establishment of a reward system based on the principle that significantly higher awards are given to the best and the most responsible employees. The use of MAS is most evident through the establishment of the company's style of management, but also through the systems of teamwork and task delegation. Managers can apply LTO in a wider organisational context and in planning through a process of selection for new workers, staff maintenance and layoffs.

Therefore, the value differences measured by Hofstede's value dimensions (HVD) can highlight the main features of employee behaviour at work and the value system of the observed respondents, which can be very useful both for business decision makers at the enterprise level and through political/administrative decisions or attracting investment at the state policy level.

\section{DATA COLLECTION AND RESEARCH METHODOLOGY}

\subsection{Scope and purpose of research}

The subject of this study is testing HVD as an indicator of the organizational culture of employees in the private and public sectors in their territories, which can be used for determining the state of human resources $(\mathrm{HR})$ at the regional level. We would like to examine to what extent the value profiles can be used to show similarities and differences between the public and private sectors, whether we can talk about public sector culture and private sector culture through value profiles. The paper aims to highlight the importance of values in HRM in achieving a more successful management system. Therefore, it can be hypothesized that: $\mathrm{H} 1$ : There are value profiles of employees in the private and public sectors in different countries / regions, which are formed on the basis of HVD and determine the state of $\mathrm{HR} ; \mathrm{H} 2$ : these value profiles differ between countries and between public sector employees and private sector employees in 6 countries/7 regions.

\subsection{Research process and sampling}

The research was conducted on a sample of employees in enterprises and local administrative units in 2013 in six European countries: Croatia, Italy, Hungary, Romania, Slovenia and Serbia. Respondents are employees from the same city/region (employed in the public and private sectors from the same service industry in their territories). Along with the sociodemographic questionnaire, a custom instrument "Values Survey Module 1994 (VSM 94) International Questionnaire (Copyright @ Geert Hofstede BV)" was used, standardised on the world population. Sampling was done strictly according to the Hofstede research requirements. The questionnaires were translated into Hungarian, Serbian, Slovenian, Croatian, Italian and Romanian.

The total number of questionnaires sent out is 1580 , out of which 1248 questionnaires were returned (78.98\%). In total, 1166 questionnaires were filled out correctly $(73.79 \%)$, which is the number that entered into further data processing and analysis. Questionnaires were distributed at local administrative units and enterprises that had accepted participation with the support of the managers of the enterprises and the mayors of the municipalities. Employees were encouraged to fill out the questionnaire anonymously and were informed about the procedure orally and in writing. The high response rate is the result of invested effort for a long period of time on planning the distribution of the questionnaire, flexibility with timing and the personal contact of authors with various institutions in all six countries through international and interdisciplinary projects.

The sample was divided into subsamples: 729 respondents from the private sector and 437 from the public sector. Each subsample was analysed according to the country/region criteria (in the case of Serbia, the north and south of the country). Respondents from Slovenia (public sector) and Italy (private sector) were taken as "control subsamples". The research 
included 567 men and 599 women, aged $19-72$ years, with the highest percentage of respondents in the age range $40-50$ years (435 respondents, $37.2 \%$ ). In order to maintain balance within the sample, employees' management levels have been also taken into account, with employees from the top (75), middle (281) and lower management (810) and a balanced number of respondents with all educational levels, i.e. higher education (424), high school education (458) and highly qualified/qualified/semi-qualified (284).

\subsection{Variables}

The independent variables of the model are categorical variables: the region/state of residence of the enterprise/local administrative unit (private/public sector)- Croatia (eastern, Vukovar - Srijem county and Osijek - Baranja county), Italy (north, Province di Monza e della Brianza), Hungary (north-east and south, Baranya and Hajdú - Bihar), Romania (western, Județul Timiş and Județul Caraş - Severin), Slovenia (western, Goriška region), the southern Serbia region (Jablanica and Pčinja districts) and the northern Serbia region (south Bačka and north Bačka districts). The dependent variables are the employees' HVD as measured by indexes: PDI, IDV, MAS, UAI and LTO (characteristics).

\subsection{Mathematical - statistical data processing}

The data collected in this study were processed by selected mathematical and statistical procedures. We started with processing data at the level of descriptive statistics on nonparametric values. The characteristics of respondents' answers on HVD, in relation to whether they work in the private or public sector, or from a particular country/region, have nonparametric properties and have been analysed with nonparametric procedures by frequency distribution. Multivariate methods of MANOVA and discriminative analysis were used. The following univariate methods were used: Roy's test, Pearson's contingency coefficient, multiple correlation coefficient (R), the coefficient of discrimination, Student's t-test for proportions, Mahalanobis distance and cluster analysis. Hofstede's formulas were used for calculating the value dimensions indexes: PDI, IDV, MAS, UAI and LTO. Methods of proving the existence of similarities or differences between subsamples confirm the hypothesis of similarity or reject it (confirm the alternative hypothesis), or show the existence of differences. A critical $p$-value was used; if $p$ $>0.100$, there is no reason not to accept the initial hypothesis. To discard the initial hypotheses, two thresholds of significance were used: $0.10>P>0.05$ and $p<$ 0.05 (significant differences).

\section{ANALYSIS OF HOFSTEDE'S VALUE DIMEN- SIONS OF EMPLOYEES IN THE PRIVATE AND PUBLIC SECTORS}

By comparing the scores for employees between countries and between sectors, a few tendencies can be seen. There is a tendency of equalizing scores in all evaluated dimensions for Serbia and Croatia, except for the IDV dimension, which is significantly higher for Croatia. PDI is extremely low for Italy, which is specific because it includes only respondents from the private sector; it shows a close relationship without obstacles between workers and employers. Also, PDI are similar for all countries/regions, except for Romania, which has a lower PDI compared to other countries. UAl seems to be a feature of former Yugoslav countries and it is typical for Croatia, Serbia and Slovenia, and also for Hungary, which has the highest score (the lowest is for Romania). The MAS dimension varies the most, while LTO is quite constant, with a slightly higher score for Romania.

Table 1: Sample per country and sector

\begin{tabular}{|c|c|c|c|c|c|c|}
\hline \multirow{2}{*}{\multicolumn{2}{|c|}{$\begin{array}{c}\text { Country/region/gender/ } \\
\text { management }\end{array}$}} & \multicolumn{2}{|c|}{ Gender (n; \%) } & \multicolumn{2}{|c|}{ Private/Public sector (n) } & \multirow{3}{*}{$\begin{array}{r}\text { Total } \\
176\end{array}$} \\
\hline & & \multirow{2}{*}{$\begin{array}{l}\text { male } \\
67 ; 38.1\end{array}$} & \multirow{2}{*}{$\begin{array}{l}\text { female } \\
109 ; 61.9\end{array}$} & \multirow{2}{*}{$\begin{array}{r}\text { Private } \\
95\end{array}$} & \multirow{2}{*}{$\begin{array}{r}\text { Public } \\
81\end{array}$} & \\
\hline \multirow{7}{*}{$\begin{array}{l}\text { Country } \\
\text { /region }\end{array}$} & Croatia & & & & & \\
\hline & Italy & $14 ; 46.7$ & $16 ; 53.3$ & 30 & 0 & 30 \\
\hline & Hungary & $46 ; 29.5$ & $110 ; 70.5$ & 115 & 41 & 156 \\
\hline & Romania & $51 ; 44.7$ & $63 ; 55.3$ & 50 & 64 & 114 \\
\hline & Slovenia & $11 ; 26.2$ & $31 ; 73.8$ & 0 & 42 & 42 \\
\hline & Southern Serbia & $169 ; 61.2$ & $107 ; 38.8$ & 204 & 72 & 276 \\
\hline & Northern Serbia & $209 ; 56.2$ & $163 ; 43.8$ & 235 & 137 & 372 \\
\hline \multicolumn{2}{|l|}{ Total } & $567 ; 48.6$ & $599 ; 51.4$ & 729 & 437 & 1166 \\
\hline
\end{tabular}


Table 2: HVD indexes by private/public sector by country/region.

\begin{tabular}{|l|c|c|c|c|c|}
\hline $\begin{array}{l}\text { country/region (private/public sector)/ } \\
\text { value dimensions }\end{array}$ & PDI & UAI & MAS & IDV & LTO \\
\hline Croatia - private sector & 48.89 & 78.52 & 20.32 & 81.79 & 50.95 \\
\hline Croatia - public sector & 37.35 & 87.72 & 30.86 & 69.70 & 43.46 \\
\hline Croatia & 43.58 & 82.76 & 25.17 & 76.22 & 47.50 \\
\hline Italy - private sector & 19.00 & 81.00 & 8.67 & 64.00 & 51.33 \\
\hline Hungary - private sector & 59.30 & 101.43 & 11.83 & 60.22 & 56.52 \\
\hline Hungary - public sector & 55.98 & 97.19 & 24.63 & 66.46 & 49.26 \\
\hline Hungary & 58.43 & 100.32 & 15.19 & 61.86 & 54.61 \\
\hline Romania - private sector & 35.50 & 42.10 & 41.40 & 58.9 & 66.00 \\
\hline Romania - public sector & 29.22 & 50.16 & 53.44 & 53.75 & 55.94 \\
\hline Romania & 31.97 & 46.62 & 48.15 & 56.00 & 60.35 \\
\hline Slovenia - public sector & 38.33 & 97.26 & -21.43 & 83.69 & 54.29 \\
\hline southern Serbia - private & 34.85 & 84.07 & 38.92 & 66.05 & 41.18 \\
\hline southern Serbia - public sector & 51.66 & 62.50 & 43.19 & 63.46 & 51.39 \\
\hline southern Serbia & 39.24 & 78.44 & 40.04 & 66.16 & 43.84 \\
\hline northern Serbia - private sector & 38.17 & 88.94 & 22.64 & 72.79 & 48.68 \\
\hline northern Serbia - public sector & 53.76 & 84.52 & 19.49 & 59.45 & 49.34 \\
\hline northern Serbia & 43.91 & 87.31 & 21.48 & 67.88 & 48.92 \\
\hline
\end{tabular}

It is noticeable that there are differences between and within countries/regions. For example, Croatia has an almost 10 percentage unit (p.u.) difference between employees in the public and private sectors, followed by Hungary (4-7 p.u.), Romania (5-8 p.u. with the exception of LTO 11 p.u). In southern Serbia there is a major difference between the scores for PDI (17 p.u.), UAI (22 p.u.) and LTO (10 p.u.), while in northern Serbia for PDI there is 15 p.u. and IDV 13 p.u. difference.

The index score for the public sector shows a similarity of PDI for both Serbian regions and Hungarian respondents. Croatian and Slovenian respondents also show a similarity for PDI, while Romanian respondents from the public sector have the lowest index of PDI. The relative uniformity of PDI scores for Serbian and Romanian respondents can be seen for respondents from the private sector, while the index scores for Croatian and especially Hungarian respondents are higher.

For the respondents in the public sector in general, a balanced but generally higher index score of UAI is observed, except for the Romanian and southern Serbian samples, whose indexes are lower than an average of 22 p.u. For UAl, we again see balanced scores for Serbian respondents, which are mostly similar to Italian and Croatian respondents, while the score of Romanian respondents in enterprises is half the value of the score of Serbian respondents. At the same time, Hungarian respondents have higher UAI than respondents from other countries/regions.
For MAS, the differences between respondents can be seen even more clearly, where respondents in companies from northern Serbia and Croatia have more emphasized elements of feminine organizational culture, unlike southern Serbia and Romania, where the scores are almost doubled. At the same time, the number of MAS participants from Hungary is half that of respondents from the northern Serbia and Croatia, as well as extremely low MAS in control group from Italy. However, it is still 10 p.u. lower than the highest score of MAS, which is a characteristic of Romanian public sector employees. It is clear that respondents from the public sector in southern Serbia significantly differ in terms of masculine working culture than their colleagues in other countries (including northern Serbia) because their index score is almost twice as high.

IDV indexes are almost equal for employees from the public sector (except Slovenia, where this index is much higher), while the index of Romanian respondents is somewhat lower compared with that of other index scores. Respondents from enterprises have the highest score in Croatia and the lowest in Romania. Serbia is characterized by a high score for respondents from the north of the country, higher than the score in Hungary. Reduced LTO is noticeable for respondents from southern Serbia compared to northern Serbia and Croatia, while respondents from Hungary and Romania have significantly higher scores. LTO for the public sector is similar in all countries/regions, except in Romania where it is slightly higher. 


\subsection{Differences between respondents employed in the private sector}

Based on the value of $p=.000$ (analysis MANOVA: $n=5$, $\mathrm{F}=6.827$ ) and $\mathrm{p}=.000$ (discriminative analysis: $\mathrm{n}=5$, $\mathrm{F}=6.871$ ) there is a difference and a clearly defined border between subsamples of respondents.

As $p<.1$, there is a significant difference between respondents (country/region) in value dimensions: PDI (.020), UAI (.000), MAS (.000), IDV (000) and LTO (.000). The discrimination coefficient refers to the fact that the biggest contribution to the discrimination is between subsamples of respondents in value dimensions as follows: MAS (.121), UAI (.037), LTO (.033), IDV (.022) and PDI (.017).

The logical sequence of research was to determine the characteristics and homogeneity of each subsample and the distance between subsamples by country/ region. A clearly defined border between subsamples of respondents has been found, i.e. the possibility to determine the characteristics of each subsample and then the value profiles, based on the responses on the HVD. The MAS index defines the features of each subsample the most, since its contribution to features is
$52.601 \%$, followed by: UAI (16.087\%), LTO (14.368\%), IDV (9.565\%) and PDI (7.391\%). Furthermore, as an example, 64 out 95 respondents have characteristics of the Croatian subsample, which shows higher homogeneity; this means that 31 respondents have other characteristics and not characteristics of their group. The homogeneity of the Croatian sample is therefore $67.37 \%$, which confirms the chance that a respondent with similar characteristics would belong to a Croatian subsample; consequently it is possible to forecast with a certain reliability. Similarly, the homogeneity of the Italian sample is $53.33 \%$, the Hungarian $62.61 \%$, the Romanian $74 \%$, the southern Serbian $57.35 \%$ and the northern Serbian $61.28 \%$. This confirms the quality of the samples and their representativeness.

By calculating Mahalanobis distance between countries/regions of respondents, we get one more indicator of similarity or difference.

Based on the displayed dendrogram, respondents from Croatia and northern Serbia are the closest to one another. The biggest difference is between respondents from Croatia and Italy. A distance of .70 lies between Croatia and northern Serbia in relation to southern Serbia, followed by a distance of .75

Table 3: Significance of differences between subsamples - private sector.

\begin{tabular}{|c|c|c|c|c|c|}
\hline & C & R & F & p & k.dsk \\
\hline PDI & .190 & .135 & 2.707 & .020 & .017 \\
\hline UAI & .219 & .188 & 5.285 & .000 & .037 \\
\hline MAS & .337 & .329 & 17.559 & .000 & .121 \\
\hline IDV & .220 & .181 & 4.932 & .000 & .022 \\
\hline LTO & .227 & .192 & 5.535 & .000 & .033 \\
\hline
\end{tabular}

k.dsk - discrimination coefficient

Table 4: Mahalanobis distance between subsamples - private sector.

\begin{tabular}{|l|c|c|c|c|c|c|}
\hline & Croatia & Italy & Hungary & Romania & $\begin{array}{c}\text { southern } \\
\text { Serbia }\end{array}$ & $\begin{array}{c}\text { northern } \\
\text { Serbia }\end{array}$ \\
\hline Croatia & .00 & .93 & .96 & .73 & .71 & .43 \\
\hline Italy & .93 & .00 & .75 & 1.39 & .83 & .74 \\
\hline Hungary & .96 & .75 & .00 & 1.29 & .95 & .97 \\
\hline Romania & .73 & 1.39 & 1.29 & .00 & .88 & .72 \\
\hline southern Serbia & .71 & .83 & .95 & .88 & .00 & .55 \\
\hline northern Serbia & .43 & .74 & .97 & .72 & .55 & .00 \\
\hline
\end{tabular}

Table 5: Grouping of subsamples of countries/regions - private sector.

level

Croatia, northern Serbia relation

Croatia (with northern Serbia), southern Serbia 
between groups in Italy and Hungary. A distance of .85 is calculated between a group led by Croatia (with northern Serbia and southern Serbia) and Romania. Finally, the greatest distance of 1.40 is between the

Figure 1: Dendrogram of subsamples - private sector.

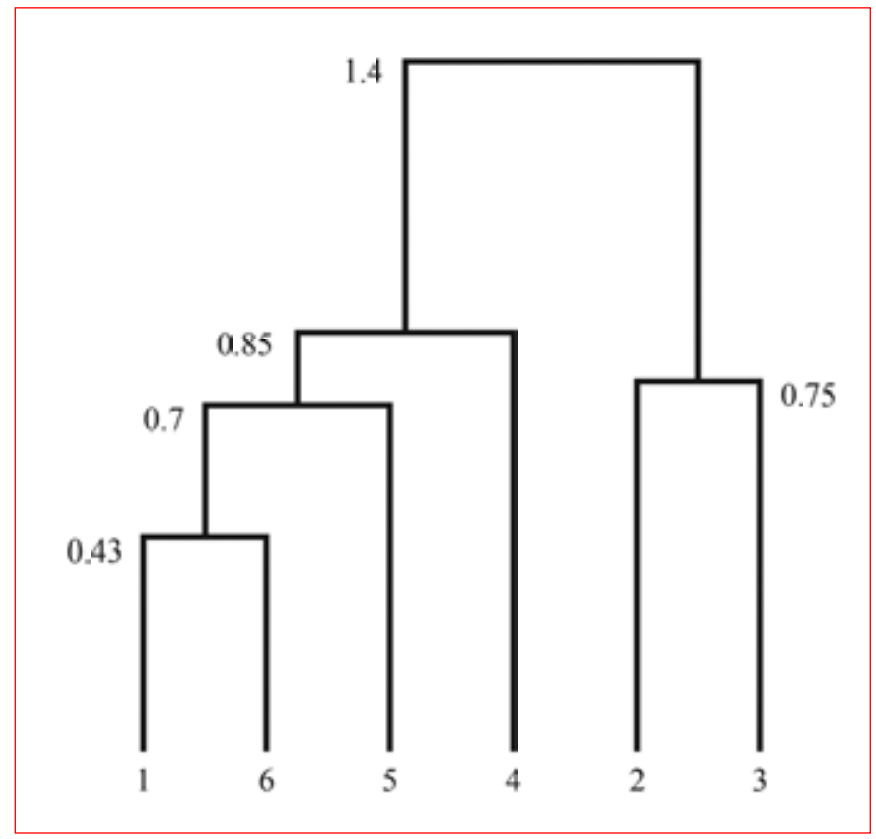

Croatia (1) Italy (2) Hungary (3) Romania (4) southern Serbia (5) northern Serbia (6). group led by Croatia (with northern Serbia, southern Serbia and Romania) and Italy (with Hungary). It can be observed that there is a tendency for the grouping Serbian and Croatian subsamples and their separation from the Hungarian and Italian subsamples, which are grouped on the other branch of the dendrogram.

The ellipses show the relationship between each subsample and its characteristics, in relation to the two most discriminating HVD: MAS and UAI. Respondents' answers had two types of modalities: 1) "of utmost importance", "very important", "of moderate importance", "of little importance", "of very little or no importance"; and 2) "always", "usually", "sometimes", "seldom", "never".

The horizontal axis is MAS (represented by question 7) presented with responses on a 5-point scale. The vertical axis is the UAI (question 13) also presented with a responses on a 5-point scale. It can be observed that in relation to MAS for the Hungarian subsample (3) the most frequent answer is 'of little importance', and for the Romanian subsample (4) 'of utmost importance'. For UAl, for the Italian subsample (2) the most frequent answer is 'always', while for the Romanian (4) 'usually'. There is a similarity of answers from northern and southern Serbia ( 6 and 5) which can be seen from the overlapping of the two ellipses.

Figure 2: Ellipses representing countries/regions of respondents in relation to their answers for MAS and UAI - private sector.

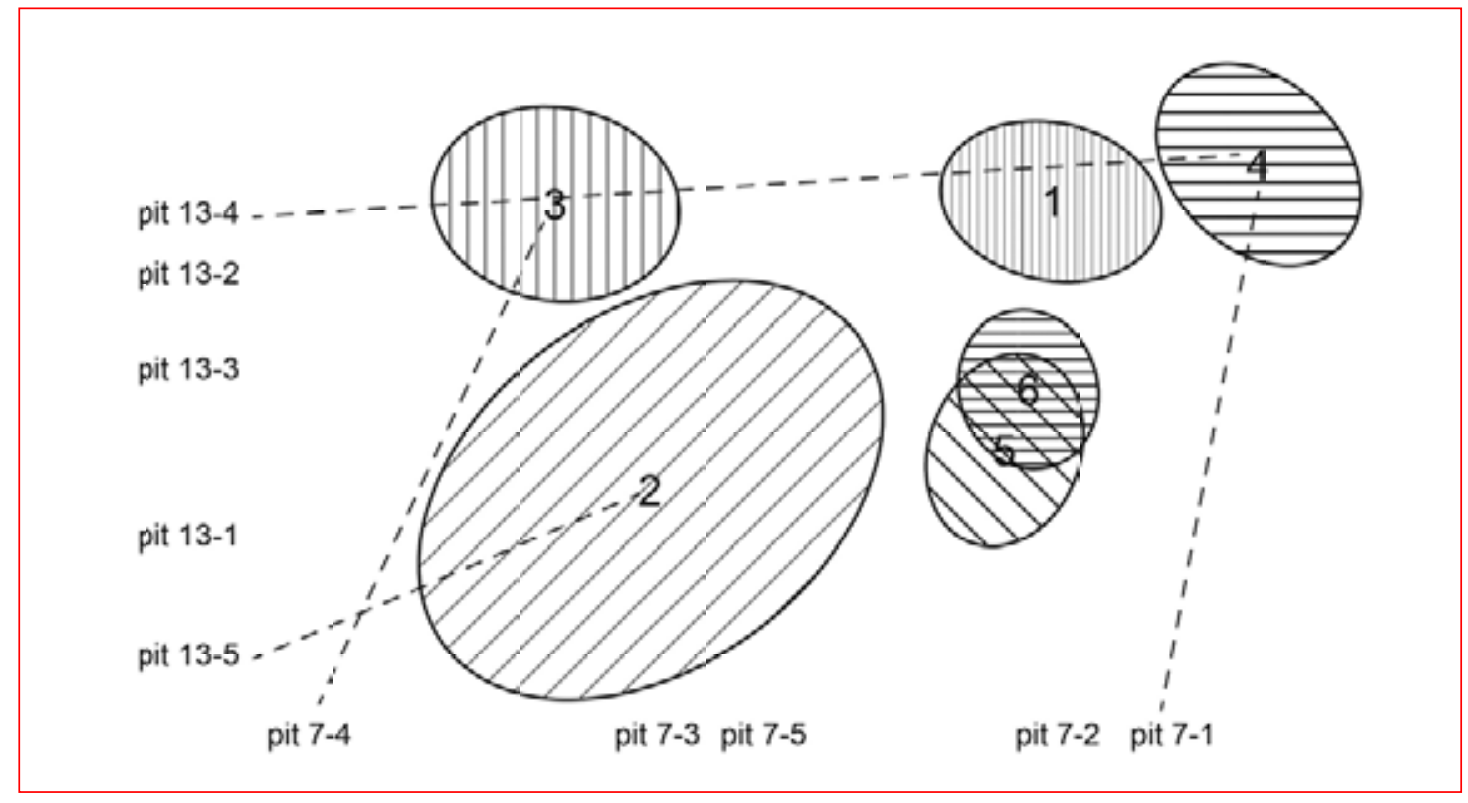

pit = question; Croatia (1); Italy (2); Hungary (3); Romania (4); southern Serbia (5); northern Serbia (6); of utmost importance (question 7-1); very important (question 7-2); of moderate importance (question 7-3); of little importance (question 7-4); of very little or no importance (question 7-5); never (question 13-1); usually (question 13-2); sometimes (question 13-3); usually (question 13-4); always (question 13-5). 


\subsection{Differences between respondents employed in public sector}

Based on value of $p=.000$ (MANOVA analysis: $n=5$, $F=5.277$ ) and $p=.000$ (discriminative analysis: $n=5$, $\mathrm{F}=5.266)$, there is a difference and clearly defined border between respondents.

As $p<.1$, there is a significant difference between respondents in: PDI (.000), MAS (.000), IDV (.000) and LTO (.000). A latent characteristic is a characteristic in which there is no clear difference between respondents and the discriminative analysis included it in the research structure. A latent characteristic here is: UAI (.146). The discrimination coefficient shows that the biggest difference between respondents is at: LTO (.088), IDV (.084) and PDI (.082).

Based on the same methodology applied for the analysis of private sector respondents, the characteristics and homogeneity of each subsample has been determined and the distance between subsamples by country/region. Clearly defined borders between subsamples of respondents were found, which made the characteristics of each subsample possible to determine; this has enabled the formation of value profiles. LTO defines the features of each subsample of respondents the most because its contribution to features is $25.882 \%$, along with IDV $(24.706 \%)$ and PDI (24.118\%), MAS $(20,000 \%)$ and to a lesser extent UAI (5.294\%). The homogeneity of the Croatian sample is $59.26 \%$, Slovenian $59.52 \%$, Hungarian $58.54 \%$, Romanian $73.44 \%$, southern Serbian $66.67 \%$ and northern Serbian $53.28 \%$. The Mahalanobis distance between countries/regions of respondents shows one more indicator of similarity or difference.

Based on the displayed dendrogram and Table 7, respondents from Croatia and northern Serbia are the closest (.55), followed by a distance of .74 between them and a group of Slovenians and south Serbians. A distance of .88 is calculated between groups from Croatia (with northern Serbia) and Romania. It can be observed that there is a tendency for the grouping of Serbian and Croatian subsamples again. Both form a

Table 6: Significance of differences between subsamples - public sector.

\begin{tabular}{|c|c|c|c|c|c|}
\hline & C & R & F & p & k.dsk \\
\hline PDI & .345 & .265 & 6.501 & .000 & .082 \\
\hline UAI & .195 & .137 & 1.645 & .146 & .018 \\
\hline MAS & .348 & .282 & 7.458 & .000 & .068 \\
\hline IDV & .344 & .296 & 8.320 & .000 & .084 \\
\hline LTO & .283 & .229 & 4.796 & .000 & .088 \\
\hline
\end{tabular}

k.dsk - discrimination coefficient

Table 7: Mahalanobis distance between subsamples - public sector.

\begin{tabular}{|l|c|c|c|c|c|c|}
\hline & Croatia & Hungary & Romania & Slovenia & Serbia south & Serbia north \\
\hline Croatia & .00 & .94 & .91 & 1.28 & .92 & .55 \\
\hline Hungary & .94 & .00 & 1.17 & 1.36 & 1.09 & .77 \\
\hline Romania & .91 & 1.17 & .00 & 1.31 & .90 & .67 \\
\hline Slovenia & 1.28 & 1.36 & 1.31 & .00 & .74 & 1.05 \\
\hline Serbia south & .92 & 1.09 & .90 & .74 & .00 & .59 \\
\hline Serbia north & .55 & .77 & .67 & 1.05 & .59 & .00 \\
\hline
\end{tabular}

Table 8: Grouping of subsamples of countries/regions - public sector.

\begin{tabular}{|l|c|}
\hline level & relation \\
\hline Croatia, Serbia north & .55 \\
\hline Slovenia, Serbia south & .74 \\
\hline Croatia, Romania & .88 \\
\hline Croatia, Hungary & 1.06 \\
\hline Croatia, Slovenia & 1.49 \\
\hline
\end{tabular}


separate branch of dendrogram with the Hungarian and the Romanian subsamples, while Slovenian and south Serbian subsamples are grouped on the other branch of the dendrogram.

The ellipses show the relationship between each subsample and its characteristics in relation to the two most discriminating HVD: IDV and PDI, confirming the dendrogram results. The horizontal axis is IDV (represented with question 8), while the vertical axis is PDI (question 3) both presented with responses on a 5-point scale. Figure 4 shows the clear distinction of the Slovenian subsample (4) from the other subsamples. In relation to IDV, for the Slovenian sample the most frequent answer is 'of the utmost importance', and for the Croatian sample (1) 'of moderate importance. For PDI, the most frequent answer for the sample from south Serbia (5) is "of utmost importance" and for the Croatian subsample it is 'of moderate importance'.

With the research and analysis presented here, the hypotheses of the paper have been undoubtedly accepted. It has been confirmed that there are value profiles of employees in private and public sector in different countries / regions that are formed on the
Figure 3: Dendrogram of subsamples - public sector.

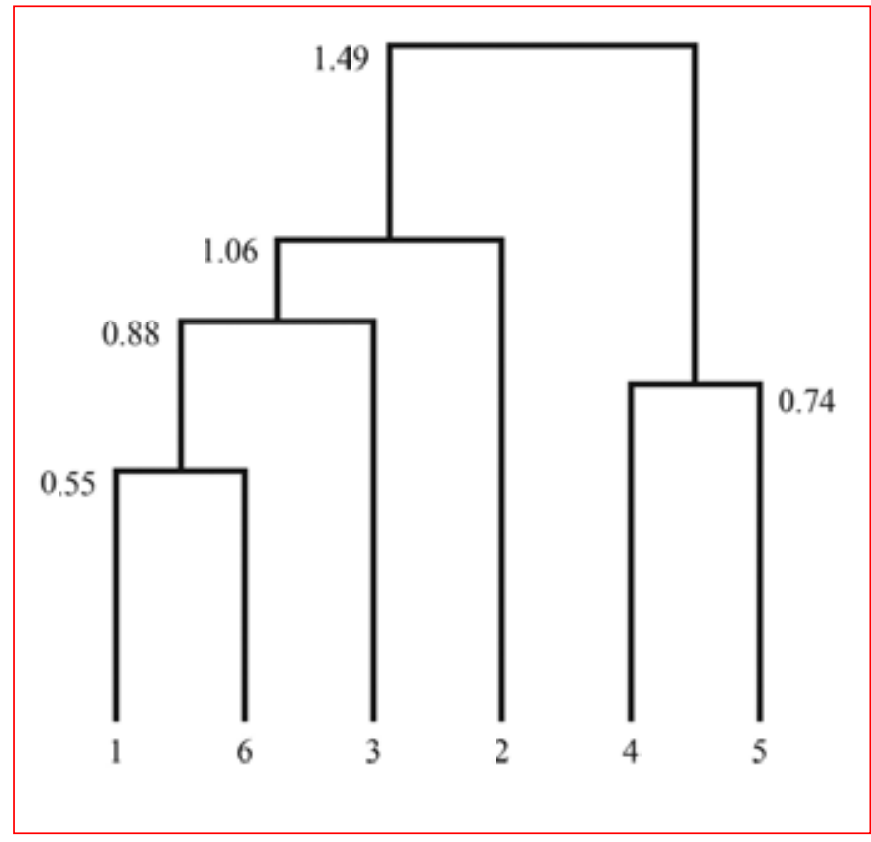

Croatia (1) Hungary (2) Romania (3) Slovenia (4) Serbia south (5) Serbia north (6)

Figure 4: Ellipses representing countries/regions of respondents in relation to their answer for IDV and PDI - public sector.

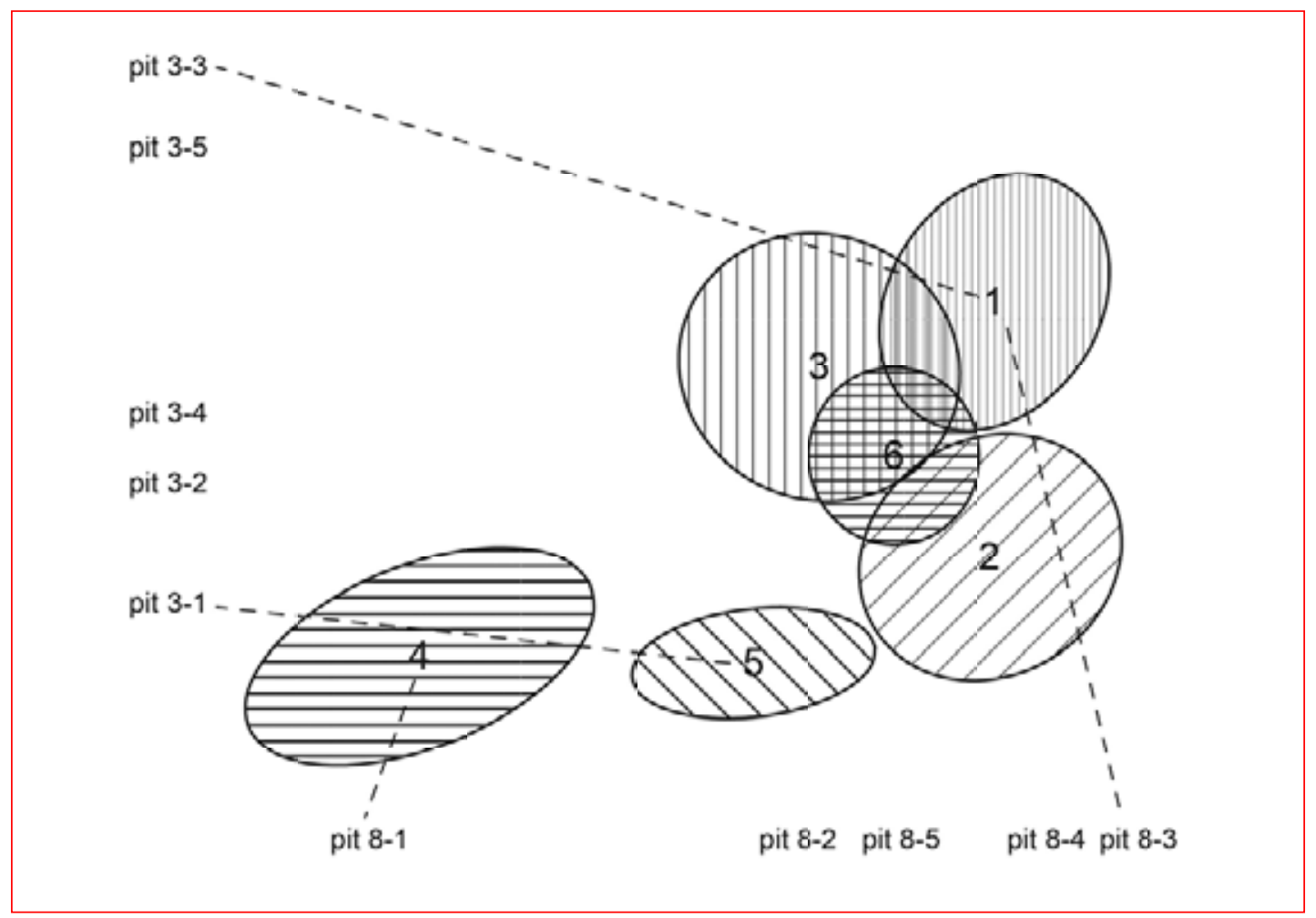

pit = question; Croatia (1); Hungary (2); Romania (3); Slovenia (4); southern Serbia (5); northern Serbia (6); of utmost importance (question 8-1); very important (question 8-2); of moderate importance (question 8-3); of little importance (question 8-4); of very little or no importance (question 8-5); of utmost importance (question 3-1); very important (question 3-2); of moderate importance (question 3-3); of little importance (question 3-4); of very little or no importance (question 3-5). 
basis of HVD and can be used to determine the state of $\mathrm{HR}$ at the regional level. There is a difference between enterprises and between local administrative units in relation to the individual responses of employees on HVD. Value profiles differ between public sector employees and private sector employees in the 6 countries/7 regions.

\section{SYNTHESIS OF RESEARCH FINDINGS}

In accordance with previously established objectives, methodological approach and research questions and based on the research performed, it can be concluded that it is possible to determine the characteristics of each subsample and thus the value profiles of employees in each country. The study showed the smallest difference between subsamples of respondents from northern Serbia and Croatia, and the biggest difference between employees in the private sector in Romania and in Italy (alongside Hungary). For the public sector, there is a similarity of the results of respondents from Croatia and North Serbia and a sharp difference between respondents from Croatia and Italy. Finally, the study found the greatest distance between employees of the public sector in Croatia, Serbia and Romania on one side and Italy and Hungary on the other.

The most important research results are related to the proven similarity of HVD scores of employees in Croatia and Serbia, which can be explained by the large similarities in organisational behaviour, i.e. mentality, between these nations, as well as cultural and social affinities, years of life together in the same country and the similarity of administrative culture. Also, research has shown that the post-Yugoslav states in this research are very similar in terms of UAl, which again could be explained by the similarities in the cultural setting, similar economic standards and way of life, as well as common social values that were dominant in Yugoslavia, namely in life and work-related social relations. These values would include, among others: a tendency to improvise, aversion to planning, risk aversion, lack of innovation and an entrepreneurial way of thinking, and so on. The causes of these similarities are also connected with the development that these nations have recorded through history, as well as similar privatization challenges and transitional circumstances that have created additional patterns of behaviour in the observed countries. The research results suggest the direction that policymakers in these countries need to take in order to understand and then address and/or change work habits, systems of values, ways of thinking and behaving in the organisational setting, e.g. administration practices, with the goal of securing the capital for faster and greater economic growth. Especially for Croatia and Serbia, which have such similarities in organisational culture, with decreasing MAS and growing IDV, it appears that the potential for innovation is not yet fully understood by the authorities, who do not sufficiently value this cultural shift. There is a constant brain drain from these countries and much more can be done with regard to making favourable policy, and a better societal environment and structure for innovation.

\section{IMPLICATIONS FOR HRM}

Each region, therefore, has its own specificity and its unique employee value profile. This paper forms a concept of the value dimensions of employees as an important HR development factor. With this methodology, values can be observed in a more detailed way. HRM managers can use value profiles for various HRM functions within organisations as well as at the regional level. The regional value profiles of employees can be used to identify potentials of HR of a particular region or municipality, indicate possible directions of development of the region and its resources, and to that end, to select an adequate intervention in HRM at the local level.

Any reorganisation of an enterprise or local administrative unit should involve adequate knowledge about HR and their values in order to induce better management, professionalisation of work and the creation of new competencies of employees. A better understanding of the values at the core of employees' motivation is very important, especially with regard to public service reform, which is on-going in many of the countries involved in this research; learning about the values of public servants can offer better insight into the potential and quality of public services, the pace of reform and what can be expected in this regard in the future. It is important to be open to innovation and development, which comes from the employees themselves. Given the unfavourable socioeconomic indicators and persistent poverty rates in the countries of South East Europe, it is time for policy makers to pay attention to understanding HR as the most valuable national resource.

How can a HRM manager use value profiles to shape HRM functions? First, an HRM manager should be able to create and implement such planning for HR development that would standardise knowledge about employees' values at the organisational level. This includes knowledge of the characteristics of these values. Second, in addition to a standard selection 
procedure, internal training or performance feedback delivery, HRM managers should always include a questionnaire of employees' values. This practice should lead to their ability to create value profiles for teams based on calculations using frequencies, as in our research. Third, HRM managers should be able to compare the value profiles of their employees (teams).

For example, with regard to the creation of teams, an HRM manager would be interested to know what kind of capacity the teams of employees in a certain country or region have or are able to show. Results of this study show that differences between value profiles are significant at both national and regional level and imply that values should be taken into account in functions of HRM i.e. in the processes of 1) selection, hiring, training and onboarding and retention of personnel, on one side and on the other side 2) keeping employees relations complementary to development and growth of an organisation/company (e.g. teaming up, adjustments to new trends and course change, testing new methodologies or innovative techniques).

More specifically, when calculating value profiles, an HRM manager can compare the groups of employees within a company or its branches in different countries and assess their strengths as (national/regional) teams and address their weaknesses through targeted training, the change of focus on certain training topics and the dynamics of the training process. The added value of such an approach would be in using an organization's own resources better to address its weaknesses. In other words, HRM managers can better use their own skills in selection and hiring by asking questions which go one step further in knowing their (future) employees, i.e. questions about their values.

In the selection process, HRM managers should go beyond the selection of one employee to fit the team. Instead, HRM managers should use information on employees' values as a team to assemble the team. In this way, HRM managers can get insight into employees' relations and characteristics, and get information about their motivation as a group. Such an insight can create or improve working conditions towards a more genuine result-oriented working environment that fits each individual. In this way, the HRM manager is more able to engineer teams according to the requirements of a specific work place or task within a company or an assignment (e.g. in public private partnerships of different scales) looking at the specifics of a current or future teams (e.g. in takeovers or downsizing). The value profiles give a manager instant insight into possible team combinations and whether old/current set up should be retained or used in another setting, and how useful merging the teams would be at the national or international level.

With regard to organisational learning, we can expect that value profiles can give HRM managers firsthand information about the collective strength of a group of individuals and how prone such groups are towards, for example, change or learning; this can directly concern selection, retention and dismissal, while being more sensitive to giving space for career growth and creativity. An HRM manager can save a lot of time and money by addressing a potential problem at the level of values. For example, if an HRM manager knows that a team has a lack of aptitude for learning as a group, it can save time and money before this becomes a problem. Or, in the case of strong individualism, an HRM manager can prevent an over-individualistic approach which could overshadow employees' competencies and innovativeness.

\section{LIMITATIONS OF THE RESEARCH AND FUTURE COURSE OF RESEARCH}

The approach presented here also has its limitations, which can be, however, addressed with a more elaborate selection of variables, i.e. values that are constituent elements of a certain desired outcome. For example, the approach presented here can be further used to identify the constituent elements of a fast learning team that quickly uses new information and methods. This implies the search for a combination of values and value profile combinations that can show an inclination towards learning and other values linked to learning, such as higher motivation for achievement, team work and recognition.

\section{REFERENCES}

Bakacsi, Gy., Takács, S. 1998. Honnan - Hová? A nemzeti és szervezeti kultúra változásai a kilencvenes évek közepének Magyarországán. (From where to where? The national and organizational culture changes in Hungary of the mid-nineties). Vezetéstudomány 26 (2): 15-22.

Bakacsi, Gy., Takács, S., Karacsonyi, A., Imrek, V. 2002. Eastern European cluster: tradition and transition. Journal of World Business, 37 (1): 69-80.

Bodea, D. 2013. Values of Romanian Employees, Bucharest: Result Development.

Cohen, J.S. and Federico G. 2001. The Growth of the Italian Economy, 1820-1960. Cambridge: Cambridge University Press.

Falkné Bánó, K. 2014. Identifying Hungarian cultural characteristics in Europe's cultural diversity in the 21 st century: a controversial issue, In: Solt Katalin (szerk.) Alkalmazott 
tudományok I. fóruma: konferenciakötet. Budapest: Budapesti Gazdasági Főiskola. 195-206.

Feather, N. 2004. Value correlates of ambivalent attitudes toward gender relations. Personality and Social Psychology Bulletin 30(1): 3-12.

Flower, R., Falassi, A. 2006. Culture Shock! Italy: A Survival Guide to Customs and Etiquette. London: Marshall Cavendish.

Gannon, M.J., Pillai, R. 2010. Understanding Global Cultures: Metaphorical Journeys through 29 Nations, Clusters of Nations, Continents, and Diversity. Los Angeles, CA: Sage Publications.

Gilliland, M. 1995. Nationalism and Ethnogenesis in the Former Yugoslavia. In Ethnic Identity: Creation, Conflict and Accommodation, edited by Lola Romanucci-Ross and George DeVos, 3rd edition. London: Sage.

Glenny, M. 2000. The Balkans: Nationalism, War and the Great Powers, 1804-1999. New York, NY: Viking.

Hofstede, G. 2001. Culture's consequences: Comparing values, behaviors, institutions and organizations across nations. Thousand Oaks, CA: SAGE Publications.

Hofstede, G., Hofstede, G. J. 2005. Cultures and organizations: Software of the mind, New York: McGraw-Hill.

Hofstede, G. J., Minkov, M. 2010. Cultures and Organizations: Software of the Mind (Rev. third edition.). New York: McGraw-Hill.

Jazbec, M. 2005. Medkulturno komuniciranje kot sestavni del poslovnega izobraževanja (Intrercultural communiucation as a integral part of business education). Ljubljana: University of Ljubljana.

Jazbec, M. 2007. Slovenian national culture \& cross-cultural training. In J. Prašnikar \& A. Cirman (2007) New emerging economies \& their culture. New York: Nova Science Publisher.

Lažnjak, J. 2011. Dimensions Of National Innovation Culture In Croatia Content Validity Of Hofstede's Dimensions, Društvena Istraživanja / Journal For General Social Issues 20(4 (114)):1015-1038.

Luca, A. 2005. Where Do We Stand? A Study On The Position Of Romania On Hofstede's Cultural Dimensions, Interact - A Study On The Position Of Romania On Hofstede's Cultural Dimensions, http://mentalite.ro (accessed 01.12.2016).

Matic, J. L. 2006. The Degree Of Uncertainty Avoidance Present In Croatian And American Undergraduate Students, A Comparative Analysis. Europe's Journal Of
Psychology. 2 (4). http://ejop.psychopen.eu/article/ view/291/html (accessed 01.12.2016).

Marinaş, C. 2010. Managementul comparat al resurselor umane (Comparative Management of Human Resources). Bucureşti: Editura Economica.

McEwan, T. 2001. Managing Values and Beliefs in Organisations. Harlow, UK: Prentice Hall.

Molnár, Zs. 2004. Magyar vezetõk nemzetközi karrierje Döntõ személyiségjegyek (Hungarian international career managers - Personality Traits), Figyelõ, 14-20 (10): 38-39.

Muruntelu, A. 2010. Cross-cultural differences in Romania, Business Support Services for Foreigners in Romania. www.scribd.com (accessed 01.12.2016).

Podrug, N. Filipović, D, Stančić, I. 2014 Analysis of cultural differences between Croatia, Brazil, Germany and Serbia, Economic Research-Ekonomska Istraživanja, 27(1): 818-829.

Prašnikar, J., Pahor, M., Vidmar Svetlik, J. 2008. Are national cultures still important in international business? Russia, Serbia and Slovenia in comparison, Journal of Contemporary Management Issues. 13 (2): 11-26.

Rajh, E., Jelena Budak, Ivan-Damir Anić 2016. Hofstede Value Survey In Croatia: Examining Regional Differences, Društvena istraživanja : Journal For General Social Issues. 25 (3): 309-327.

Rusu, S., Isac, F., Cureteanu, R. 2015. Cultural Dimensions in Romanian Management, Lucrări Ştiințifice, Seria I, 17(2): 136-140.

Spangler, W. D. 1992. The Validity Of Questionnaire And TAT Measures Of Achievement: Two Meta-Analyses. Psychological Bulletin 112: 140-154.

Struch, N., Schwartz, S. H., Van der Kloot, W. 2002. Meaning of basic values for women and men: a cross-cultural analysis. Personality and Social Psychology Bulletin, 28(1): 16-28.

Tavanti, M. 2012. The cultural dimensions of Italian leadership: Power distance, uncertainty avoidance and masculinity from an American perspective. Leadership. 8(3): 287-301.

Traquandi L and Castellucci P (2002) Leadership Italian style. In: Cross-cultural Approaches to Leadership Development, edited by Derr, CB., Roussillon, S and Bournois, F. Westport, CT: Quorum Books, 109-120.

Trstenjak, A. 1991. Misli o slovenskem človeku (Thoughts on Slovenian man). Ljubljana: Založništvo slovenske knjige. 